\title{
Towards an understanding of the dynamics of work and employment relations during austerity
}

\begin{abstract}
This study considers how public sector organisations respond to the effects of austerity. While some organisations take advantage of austerity to increase the workload of employees with little or no engagement with employees, others encourage dialogue by increasing employee and union engagement. Drawing on a systematic analysis of 26 articles, the study finds that austerity policies have negative consequences for public sector employees and presents employee voice as a potential mitigator of the negative consequences. This study is one of the first to review the small but growing literature on the effects of austerity on work and employment relationship.
\end{abstract}

Keywords

Austerity policies, employment relations, employee voice, union engagement, work 


\section{Introduction}

The effects of the 2008-2009 financial crisis were severe for the United Kingdom (UK) and Ireland (Hodson \& Quaglia, 2009; Lane, 2011; Mori, 2020). Both countries experienced a significant decline in their real gross domestic product (GDP) which also affected the finances available for public services (Stanley, 2016). As it was with other Western states, UK and Ireland had widening fiscal deficits and ballooning sovereign debts. This required an urgent political intervention in other to lessen the pressures of the crisis (Thompson, 2013). In response, the governments of the UK and Ireland introduced fiscal consolidation plans which brought about austerity and was characterised by increase in taxes and spending cuts in the public sector (Stanley, 2016).

The challenges of austerity still persist with local authorities struggling to provide social care services (Addabbo, Klatzer, Schlager, Villa, \& de Villota, 2018). While the governments in both countries have declared an end to austerity, public sector employees continue to experience a decline in real wages and are expected to work twice as hard due to the cuts in employment (Addabbo et al., 2018). Austerity policies have also created uncertainties and increased the anxiety levels of these employees. Public sector organisations were usually regarded as a secure place to work, but the recent cuts in services have made employees uneasy about the future prospects of their job (Fanelli and Brogan, 2014). For this reason, many scholars have become interested in investigating the effects of austerity. Studies have been conducted on how work and employment have been transformed (Roche \& Teague, 2012), the impact on work life balance policies, the implementation of policies aimed at engendering gender and pay equality (Hazel Conley, 2012; Gregory, Milner, \& Windebank, 2013) amongst other topics.

Yet, while there is extensive literature on the effects and economics of austerity, much less is known about the impact on employees and employee voice. Existing studies have limited their investigations to how organisations respond to austerity policies (Bach \& Stroleny, 2013; Carter et al., 2013). Such as, how austerity policies influence employee wellbeing (Cook et al., 2016). Other studies have also investigated the wider implications of austerity policies for the society; studying for example how austerity policies affect the population (McKnight, Stewart, Thomson, Tunstall, \& Vizard, 2015). Also, the dynamics of work and employment relations during austerity remains unexplored. This review paper is an attempt to address these gaps. The paper contributes to public organisation and administration literature by developing a conceptual framework that provides broad-based knowledge for implementing work and employment relations in uncertain times. This will ensure that organisations can best respond to austerity policies with as little negative effect on employee behaviour as possible. It also contributes to the limited literature examining the implications of austerity policies at organisational and employee levels and explains the boundary conditions underpinning work and employment policies during austerity and employee behaviour.

The purpose of the paper is twofold. First the paper reviews existing literature on employee and organisational responses to austerity policies. Second, the paper presents a conceptual framework for investigating the concept of employee voice in relation to union involvement 
and direct participation of workers during austere periods. The paper begins with a review of previous studies on austerity. It then moves on to discuss the methods used to undertake this review. Third, the major themes from the literature review are presented, the paper then concludes with a discussion of the key findings of the research.

\section{Literature review}

Austerity measures are often ratified in situations where the sustainability of public finances is in doubt (Born et al., 2014). The Great Recession materialized as a financial crisis in the USA in 2008/09 after the default of financial giant, Lehman Brothers, generating a seismic wave in realty markets and intensifying the derived mortgage market crisis (Végh, 2014). The high level of loan defaults led to a drop in the value of mortgages supported by securities. Several of these mortgages were traded in EU nations, hence the crisis swiftly migrated to Europe and eventually became a worldwide issue (Parnell, Spracklen, \& Millward, 2017). Ireland was declared to be in a recession in the last quarter of 2008, while Britain was authoritatively confirmed to be in a recession in the first quarter of 2009. This occurred after the Office for National Statistics (ONS) declared that the initial estimated GDP indicated a drop of $1.5 \%$ in the fourth quarter of 2008, having dropped by $0.6 \%$ in the third quarter (Vaitilingam, 2009).

Beginning in 2009, many EU nations began applying constricting policies, giving reduced significance to social concerns while shouldering the risk of slow economic growth and unemployment (Michael \& Christofides, 2020; Végh, 2014). The philosophy of austerity gradually developed against the framework of suggestions from authorities who opposed Keynesian finances, and became the central method for several governments for steering their country out of recession (Parnell, Millward, Widdop, King, \& May, 2018). Austerity, here, refers to a system of economic discipline where governments make substantial reductions to public expenditure in order to reduce public debt. Blyth (2013) defines austerity as a method of controlled deflation whereby an economy adapts to the reduction of public spending, prices and income, the aim being to reinstate competitiveness. This approach became the symbol of the time for the UK and Ireland.

In response to the debt (real and perceived) acquired by the preceding Labour administration, the Coalition Government in the UK commenced significant cuts to public expenditure, adopting several austerity procedures in its 'Comprehensive Spending Review', which delineated $£ 81$ billion worth of cuts to government units (Parnell et al., 2018). The austerity procedures were accomplished through a number of measures including spending cuts $(85 \%$ of the total austerity plan) and tax increases (15\%). Public expenditure was condensed on a national level and reduced by about $£ 245$ per capita (2.2\%) between 2009 and 2011, making the UK's austerity plan one of the largest in Europe (Reeves et al., 2013). As at 2013, over three years after the initiation of austerity measures, public spending had been reduced by about $£ 64$ billion (Parnell et al., 2018). Ireland also experienced a combination of spending cuts and tax increases amounting to over 21 per cent of the national income - GNP (FitzGerald, 2015).

A significant body of research has begun to develop in relation to the measure, pace and structure of the adjustments made to public expenditure (Clifford, 2017; Hastings, Bailey, 
Gannon, Besemer, \& Bramley, 2015; Michael \& Christofides, 2020), exploring the impact these changes have had on the living standards of the population (McKnight et al., 2015). Public organisation research has largely explored the significance of austerity measures and attempted to clarify the most adequate procedures and tactics for improving public services. However, research has rarely explored the effects of such measures on the job-holders who are ultimately responsible for delivering said public services (Kiefer, Hartley, Conway, \& Briner, 2014; Mori, 2020).

Employees in the public sector have experienced extensive job losses in addition to pay restrictions. There have also been a range of other modifications to employment terms and conditions and significant changes to pensions (Fanelli \& Brogan, 2014). While there was some growth in private sector employment during this period, there were questions regarding the nature of the new forms of employment (TUC, 2014). Legislation prohibiting unfair dismissal was made less restrictive, with employers having the right to fire employees within the first two years of employment (TUC, 2015). This has resulted in structural changes in the labour market inclined towards more insecure jobs. Indeed, the high-paying sectors has begun creating lesser jobs than lower paying ones. Due to these changes and the increased scale of underemployment, the share of public employment has declined noticeably. There is also the issue of pay restraints. Employees in the public sector have experienced an average reduction of $£ 2,245$ in wages since 2010 (TUC, 2014). The number of employees in the public sector is currently at a much-reduced percentage of the UK workforce. Those with jobs often find themselves undervalued and overworked.

Market forces ultimately shape the power relations in employment relationships. Hence, as the structure of work continues to change, so has the employment relationship. Neoclassical economic understanding suggests that an increase in demand for labour should relate to increased wages and improved employee power. Conversely, recessionary periods such as the one under study would enhance unemployment and increase labour availability, hence restricting employee power (CIPD, 2017). The latter has been the case since the global recession began in 2008. Unemployment in the UK and Ireland increased drastically and may have been even worse had some companies not taken measures to reduce the scale of redundancies (CIPD, 2017). Collective bargaining rights in the public sector have become somewhat restricted amid hardening repressive and disciplinary state machineries. Success, for labour, is increasingly about regulating the degree of concessions in their several forms.

This article reviews research evidence in order to develop a convincing narrative of the changing power dynamics in the labour market particularly with regards to the employment relationship and employee voice. As it stands, the power balance seems to be in favour of employers. This raises issues regarding the degree to which employees are able to leverage influence in the workplace. While there has been research on the implications of austerity policies for the general public, the impact on employee voice and the employment relationship remains under-researched. The paper therefore contributes to an under-explored area in the field of public organisation and administration, by theoretically analysing the effects of austerity measures on employees and employee voice within the UK and Ireland. The review 
focuses on the systems and structures that shape employee influence. There is ample research to suggest that employees may welcome involvement and participation opportunities. Thus, having a stronger voice would probably have a positive effect on employee performance and productivity.

\section{Methodology}

\section{Article selection criteria}

The articles examined in this review were chosen from data bases such as Google Scholar, EBSCO, PsychInfo and Web of Science and LOCATE. The selected articles were empirical literature in the areas of public sector management, human resource management and employment relations. The rationale for this was to determine the extent to which human resource and employment relations scholars were engaging in the issue of austerity policies and its impact on work and employment relations in the public sector. A total of 776 articles were examined in this study.

\section{Study design}

Most of the articles included in this review undertook empirical investigations in the final analysis. Empirical investigations using both quantitative and qualitative approach were included among the articles investigated. The reason for this was to ensure that the findings from this investigation were premised on research with direct evidence from employees, organisations and other relevant stakeholders. This suggests that although no field data was collected for this study, the findings from this preliminary study were premised on evidencebased principles.

\section{Sources of data and search strategy}

The search strategy used for this study included phrases that were related to austerity. Such terms were classified as the intervention (austerity, stringent financial policies and recession). It also described the outcome (employment relations, employee voice, morale, engagement, enthusiasm and commitment). Context was also an important consideration in the criteria as the study focused on the UK and Ireland. Thus, studies using Ireland, UK, England and United Kingdom were included in the search. See Table 1.

Insert Table 1 about here

\section{Selection of studies}

In line with the above article selection criteria, first, titles were screened resulting in the exclusion of some papers. Further screening was done based on abstract review. The articles that were left following the abstract review was sourced from a UK University online library data base (LOCATE). Twenty-six (26) articles were finally chosen for this review following access to the article text in full. See Figure 1 for article section criteria.

Insert Figure 1 about here

\section{Results}


Results from the search of databases mentioned earlier provided 776 articles that were considered potentially viable. In line with the article selection criteria, 26 articles were identified that had empirically investigated the implications of austerity for work and employment relations in the UK and Ireland. The range of dates were 2003 for the earliest and 2020 for the most recent. The studies had different study designs, participants and settings and used a wide range of approach including qualitative, quantitative and mixed method. See Table 2 for summary of the selected articles.

Insert Table 2 about here

\section{Discussions on key findings}

This review provides some findings that are significant. There is a possibility that it may be among the first of such reviews to examine the extent to which scholars have paid attention to the implications of austerity policies on work and employment relations in the UK and Ireland. The studies included in this review were conducted at different periods from 2003 to 2020 and consistently suggested that austerity policies had severe consequences on work and employment relations. Some of the themes derived from this review are as follows:

\section{Increased influence of HR managers}

Findings from this review showed that during the period of austerity, organisations depended more on the expertise of human resource managers to manage work and employment relation (Roche \& Teague, 2014). The focus here was soliciting the expertise of HR managers to sustain employee performance during challenging times (O'Rourke, 2020).

\section{Consultation with union representatives}

Some unionised organisations increased the participation of union representatives in the decisions on work and employment relations (Müller, Ramos-Vielba, Schmidt, Thörnquist, \& Thörnqvist, 2015; Roche \& Teague, 2014). This ensured that there were no disruptions in the business activities as the union leaders were able to explain the situation of the organisation to their members (Schmidt, Müller, Ramos-Vielba, Thörnquist, \& Thörnqvist, 2018). Other organisations took advantage of the negative economic outlook to suppress employees voice and union activities (Hazel Conley \& Page, 2016; Cook, MacKenzie, \& Forde, 2016). Interestingly, there is no study that has examined the effect of employee voice as represented by union engagement and employee participation in decision making on the relationship between austerity policies and employee relations.

\section{Management focus on efficiency.}

Organisations resorted to efficiency measures by freezing pay, cutting jobs and increasing the workload of employees (Bach \& Stroleny, 2013; Carter et al., 2013; Lumsden \& Black, 2018). Others reduced the pay scale for new employees and changed the structure of entitlements and pensions (Bach, 2016; Bach \& Bordogna, 2013; Roche \& Teague, 2014). Human resource managers were tasked with providing employees with the skills that will enable them multitask with their increased workload (Cunningham, 2016; Lindsay et al., 2014). Policies relating to gender, equality and diversity lost their immediacy (Hazel Conley \& Page, 2016). Instead, managers sought to automate some of the services that were undertaken by employees. For 
those that were not automatable, members of the public were encouraged to contribute to the community by volunteering their time to public services (Bach, 2012; Dobbins \& Dundon, 2016)

\section{Neoliberalisation and Marketisation approach}

There was increase in appetite for the private sector to undertake some of the public sector venture so as to free up capital for government to undertake other core functions. As a result, this neoliberisation approach resulted in marketisation of employment relations in the public sector which led to increased commercialisation leading to labour casualisation and erosion of working conditions (Dobbins \& Dundon, 2016; Holborow, 2012; Johnson, Rubery, \& Grimshaw, 2019; Mercille \& Murphy, 2017; Scott \& Williams, 2014).

\section{Adoption of work life balance}

An interesting finding from the study of Lewis, Anderson, Lyonette, Payne, and Wood (2017) showed that work life balance was implemented as to tool to enhance efficiency and reduce the stress of austerity. The organisations investigated help two views on work life balance. First, work life balance may be used to reduce cost with the implementation of flexible working hours and the reduction of working hours. Employees were only required to come to work only if it was necessary. In this view, it was the responsibility of management to model flexible working around employee jobs. The second view suggested that employees had the responsibility to schedule their jobs in a flexible way to enable them to operate optimally irrespective of the cuts.

\section{Survival mentality behaviour}

Studies show that although employees were unhappy with the policies introduced by their organisations to cut austerity, they were afraid to speak out for fear of losing their jobs (Cook et al., 2016). Employees were also willing to be more flexible (Loretto, Lain, Vickerstaff, \& Beck, 2013). This was because of the reduced confidence in the unions and apparent lack of alternatives due to the uncertainties caused by austerity. There was lack of trust between employees at all levels and employees who survived redundancy sought to protect their jobs and showed no support for those who were made redundant (Sahdev, 2003).

\section{Deterioration in employee well-being}

As employees experienced dissatisfaction, their well-being deteriorated (Heyes, Tomlinson, \& Whitworth, 2017). This was because of the increased workload and low or stagnated pay (Sahdev, 2003). Additionally, the low job security meant employees were working at odd and longer hours for fear of losing their jobs, thus not able to experience work life balance (Cook et al., 2016).

\section{Limitations of the study}

This systematic review is not without limitations. From the review, it was found that research investigating the implication of austerity policies on work and employment relations may be limited. Although the search strategy of the study included phrases such as austerity, stringent financial policies, recession, employment relations, employee morale, engagement, commitment and enthusiasm, there is still be the possibility that some relevant papers may have been omitted. There are chances that relevant studies in other journals may have been left out. 
There is also the challenge of generalisability. However, these challenges do not undermine the potential contributions of this preliminary study. This is because the articles included in this study have utilised a variety of methods and have included participants from a wide variety of stakeholders.

\section{Conclusions}

Employment history depicts a cyclic pattern of influence, with alternating levels of influence between employees and employers beginning in the Neolithic era, to industrialization and the rise of bureaucracy, and to present-day debates about the rise of the gig economy, globalization and decline in unionism (CIPD, 2017). In relation to the changing power dynamics in the labour market, this paper has examined the implications of austerity policies for the employment relationship and employee voice.

Evidence from the analysis highlight the various actions taken by organisations (especially in the public sector) to cope in uncertain times particularly during austerity. The study demonstrates that while austerity may be a challenge to organisations in general, their responses in terms of policy direction differed. For example, some organisations resorted to increasing employee voice as represented by direct employee participation and through union representatives, others did not (Cook et al., 2016; Roche \& Teague, 2014).

Irrespective of the policies on employee participation in decision making, or the actions taken to encourage employee engagement, the results showed that employees seem to have experienced austerity in an adverse manner (Cook et al., 2016; Sahdev, 2003). Indeed, while the current conservative government in the United Kingdom has declared an end to austerity by promising more funding to social services (Iacobucci, 2018), the reality still remains with increased zero hour contracts (Barry, 2018), increasing workload of employees in the public sector (Crawford, Stoye, \& Zaranko, 2018) and lack of urgent action to reduce the inequality in pay (Wheatley, Lawton, \& Hardill, 2018). This underscores the negative relationship between organisational austerity policies and employee relations, resulting in reduced 'employee voice' mechanisms in the workplace.

The notion of reduced influence is, however, not universal. There is some evidence of resilience from employees. For instance, several employees in the gig economy belong to unions. Nonetheless, for the major part, the principal dimensions of the employment relationship remain disengaged. Union legitimacy is questioned due to changing legislation. This is accompanied by an increase in job insecurity due to changes in the structure of the employment contract. There is increased individualization, deregulated employee protection and rights, a fixation with performance assessments and market agility, and an increase in the flexibility and precariousness of work, creating even more dispersion in the labour market (CIPD, 2017). Employers have exploited this dispersion, hence the debate about the reduced nature of employee voice and influence (Weil 2014). The structural changes in the nature of work creates new issues for the conventional and established forms of employee voice. As the CIPD (2017) puts it, the power balance in the UK has changed and employee voice has been transformed.

Consequently, this review highlights a gap that needs to be explored further and presents a conceptual framework in Figure 2 to support the gap. Additionally, there is a rarity of research on the effects of organisational austerity policies on employee voice. Although austerity debate in public organisation literature has been ongoing for the past decade (Durant \& Legge, 2001; 
Ghin, 2018), this paper makes three significant contributions to knowledge. First, there is rarity of studies that has examined the implications of work and employment relations policy introduced during austerity at employee level. As such, the boundary conditions underpinning organisational austerity policies and its effect on employees is unknown. This study provides a theoretical framework for understanding austerity policies' impact on employee behaviour. Second, the study contributes to literature by suggesting that employee voice is a composite construct comprising of union involvement and direct employee involvement in decision making. This conceptualisation provides a broader understanding of employee voice and lead to the third contribution. Thus, a third contribution of this study is conceptualisation of employee voice as a potential moderator of organisational response to work and employment relations policy during austerity and employee behaviour. In the light of the continues cuts to funding for public sector organisations (Bostock, Breese, Ridley-Duff, \& Crowther, 2020) and challenges of managing employees, employee voice provides a practical measure for public administrator in the management of employment relations. Also, the current uncertainties due to the disruptions of COVID pandemic makes the findings and contributions this study of universal appeal (Spurk \& Straub, 2020). This is especially as public sector managers worldwide are faced with making tough decisions to ensure the smooth running of their organisations (Blustein et al., 2020; Nikiforos, 2020). The framework provides broad based knowledge that managers in the public may reflect on in implementing work and employment relations policies.

Insert Figure 2 about here

While the review may be limited in scope, the analysis is viable as the articles included in the study are drawn from empirical studies that spans over 17 years covering the pre and post 2008 recession which has semblance with the current economic climate. The study shows that there is a lack of literature that addresses the implication of austerity policies for employee voice as represented by employee direct participation and union engagement using the framework of this study. The paper would, no doubt, have benefited from being based on empirical findings, and therefore, a key recommendation to come from this study is to consider the findings in an empirical setting. The next line of action for this research will be to empirically examine the moderating effects of employee voice on the relationship between austerity policies and employee relations. With the increased reliance on the expertise of human resource managers due to the uncertainties of austerity, it is expected that the findings from the empirical study will contribute both to theory and practice. 


\section{References}

Addabbo, T., Klatzer, E., Schlager, C., Villa, P., \& de Villota, P. (2018). Challenges of Austerity and Retrenchment of Gender Equality. In Gender Budgeting in Europe (pp. 57-85): Springer.

Bach, S. (2012). Shrinking the state or the B ig S ociety? Public service employment relations in an era of austerity. Industrial Relations Journal, 43(5), 399-415.

Bach, S. (2016). Deprivileging the public sector workforce: Austerity, fragmentation and service withdrawal in Britain. The Economic and Labour Relations Review, 27(1), 11-28.

Bach, S., \& Bordogna, L. (2013). Reframing public service employment relations: The impact of economic crisis and the new EU economic governance. In: Sage Publications Sage UK: London, England.

Bach, S., \& Stroleny, A. J. (2013). Public service employment restructuring in the crisis in the UK and Ireland: social partnership in retreat. European Journal of Industrial Relations 19(4), 341-357.

Barry, U. (2018). Gendered austerity policies. Global Women's Work: Perspectives on Gender Work in the Global Economy.

Blustein, D. L., Duffy, R., Ferreira, J. A., Cohen-Scali, V., Cinamon, R. G., \& Allan, B. A. (2020). Unemployment in the time of COVID-19: A research agenda. Journal of Vocational Behaviour, 119. (doi.org/10.1016/j.jvb.2020.103436)

Blyth, M. (2013). Austerity: The history of a dangerous idea: Oxford University Press.

Bostock, J., Breese, R., Ridley-Duff, R., \& Crowther, P. (2020). Challenges for third sector organisations in cutback management: a sporting case study of the implications of publicness. Public management review, 22(2), 184-205.

Carter, B., Danford, A., Howcroft, D., Richardson, H., Smith, A., \& Taylor, P. (2013). 'Stressed out of my box': employee experience of lean working and occupational ill-health in clerical work in the UK public sector. Work, Employment Society, 27(5), 747-767.

Clifford, D. (2017). Charitable organisations, the Great Recession and the age of austerity: longitudinal evidence for England and Wales. Journal of Journal of Social policy, 46(1), 1-30.

Conley, H. (2012). Economic crisis, austerity and gender equality: The UK case. Journal of European Gender Equality Law Review, 2, 14-19.

Conley, H., \& Page, M. (2016). The good, the not so good and the ugly: Gender equality, equal pay and austerity in English local government. Work, Employment Society, 32(4), 789-805.

Cook, H., MacKenzie, R., \& Forde, C. (2016). HRM and performance: the vulnerability of soft HRM practices during recession and retrenchment. Human Resource Management Journal, 26(4), 557-571.

Crawford, R., Stoye, G., \& Zaranko, B. (2018). The impact of cuts to social care spending on the use of Accident and Emergency departments in England. Retrieved from

Cunningham, I. (2016). Non-profits and the 'hollowed out'state: the transformation of working conditions through personalizing social care services during an era of austerity. Work, Employment Society, 30(4), 649-668.

Dobbins, T., \& Dundon, T. (2016). Workplace Partnership in Ireland: Irreconcilable Tensions Between an 'Irish Third Way' of Voluntary Mutuality and Neoliberalism. In Developing Positive Employment Relations (pp. 101-123): Springer.

Durant, R. F., \& Legge, J. S. (2001). Politics, public opinion, and privatization: A test of competing theories in Great Britain. Public Organization Review, 1(1), 75-95.

Fanelli, C., \& Brogan, P. (2014). Austerity, Labour, and Social Mobilizations: Rebuilding Trade Union and Working Class Politics. Journal of Studies in Social Justice, 8(2), 113-117.

Ghin, E. M. (2018). New uses of outcomes measures under austerity: the case of Danish municipalities. Public Organization Review, 18(4), 543-560. 
Gregory, A., Milner, S., \& Windebank, J. (2013). Work-life balance in times of economic crisis and austerity. Journal International journal of Sociology Social Policy, 33(9/10), 528-541.

Hastings, A., Bailey, N., Gannon, M., Besemer, K., \& Bramley, G. (2015). Coping with the cuts? The management of the worst financial settlement in living memory. Journal of Local Government Studies, 41(4), 601-621.

Hastings, T., \& Heyes, J. (2018). Farewell to flexicurity? Austerity and labour policies in the European Union. Economic and Industrial Democracy, 39(3), 458-480.

Heyes, G. (2017). Regimes of austerity. Social Movement Studies, 16(1), 21-35.

Heyes, J. Flexicurity in crisis: European labour market policies in a time of austerity. European Journal of Industrial Relations, 19(1), 71-86.

Heyes, J., Tomlinson, M., \& Whitworth, A. (2017). Underemployment and well-being in the UK before and after the Great Recession. Work, Employment Society, 31(1), 71-89.

Hodson, D., \& Quaglia, L. (2009). European perspectives on the global financial crisis: introduction. Journal of Common Market Studies, 47(5), 939-953.

Holborow, M. (2012). Austerity, capitalism and the restructuring of Irish higher education. Irish Marxist Review, 1(2), 24-36.

lacobucci, G. (2018). NHS to get funding boost of 3.4\% a year over next five years. In: British Medical Journal Publishing Group.

Johnson, M., Rubery, J., \& Grimshaw, D. (2019). Public sector employment relations after the crisis: A comparative case study analysis of UK local authorities. Economic and Industrial Democracy, $0143831 \times 18823699$.

Kiefer, T., Hartley, J., Conway, N., \& Briner, R. B. (2014). Feeling the squeeze: Public employees' experiences of cutback-and innovation-related organizational changes following a national announcement of budget reductions. Journal of Public Administration Research Theory, 25(4), 1279-1305.

Lane, P. (2011). 4 The Irish crisis. The Euro Area and The Financial Crisis, 59.

Lewis, S., Anderson, D., Lyonette, C., Payne, N., \& Wood, S. (2017). Public sector austerity cuts in Britain and the changing discourse of work-life balance. Journal of Work, Employment Society, 31(4), 586-604.

Lindsay, C., Commander, J., Findlay, P., Bennie, M., Dunlop Corcoran, E., \& Van Der Meer, R. (2014). 'Lean', new technologies and employment in public health services: employees' experiences in the National Health Service. The International Journal of Human Resource Management, 25(21), 2941-2956.

Loretto, W., Lain, D., Vickerstaff, S., \& Beck, V. (2013). Employers' use of older workers in the recession. Employee Relations.

Lumsden, K., \& Black, A. (2018). Austerity policing, emotional labour and the boundaries of police work: an ethnography of a police force control room in England. The British journal of criminology, 58(3), 606-623.

McKnight, P. O., Stewart, K., Thomson, S., Tunstall, R., \& Vizard, P. (2015). The Coalition's Social Policy Record: Policy, Spending and Outcomes 2010-2015. In.

Mercille, J., \& Murphy, E. (2017). The neoliberalization of Irish higher education under austerity. Critical Sociology, 43(3), 371-387.

Michael, M., \& Christofides, L. N. (2020). The Impact of Austerity Measures on the Public-Private Sector Wage Gap in Europe. Labour Economics, 101796.

Mori, A. (2020). Employment Relations in Outsourced Public Services: Working Between Market and State. In Employment Relations in Outsourced Public Services (pp. 1-29): Springer. 
Müller, A., Ramos-Vielba, I., Schmidt, W., Thörnquist, A., \& Thörnqvist, C. (2015). How do trade unions in the public sector respond to austerity before and since the recent crisis. Paper presented at the IREC 2015 Conference.

Nikiforos, M. (2020). Crisis, Austerity, and Fiscal Expenditure in Greece: Recent Experience and Future Prospects in the Post-COVID-19 Era. Retrieved from

O'Rourke, P. P. (2020). How NPM-inspired-change impacted work and HRM in the Irish voluntary sector in an era of austerity. Employee Relations: The International Journal.

Parnell, D., Millward, P., Widdop, P., King, N., \& May, A. (2018). Sport policy and politics in an era of austerity. In: Taylor \& Francis.

Parnell, D., Spracklen, K., \& Millward, P. (2017). Sport management issues in an era of austerity. In: Taylor \& Francis.

Roche, W. K., \& Teague, P. (2012). Business partners and working the pumps: Human resource managers in the recession. Journal of Human Relations, 65(10), 1333-1358.

Roche, W. K., \& Teague, P. (2014). Do Recessions Transform Work and Employment? Evidence from I reland. British Journal of Industrial Relations, 52(2), 261-285.

Sahdev, K. (2003). Survivors' reactions to downsizing: The importance of contextual factors. Human Resource Management Journal, 13(4), 56-74.

Schmidt, W., Müller, A., Ramos-Vielba, I., Thörnquist, A., \& Thörnqvist, C. J. E. J. o. I. R. (2018). Austerity and public sector trade union power: Before and after the crisis. European Journal of Industrial Relations, 0959680118771120.

Scott, P., \& Williams, S. (2014). The Coalition Government and employment relations: accelerated neo-liberalism and the rise of employer-dominated voluntarism. Observatoire de la société britannique(15), 145-164.

Spurk, D., \& Straub, C. (2020). Flexible employment relationships and careers in times of the COVID19 pandemic. In: Elsevier.

Stanley, L. (2016). Legitimacy gaps, taxpayer conflict, and the politics of austerity in the UK. The British journal of politics and international relations, 18(2), 389-406.

Thompson, H. (2013). UK debt in comparative perspective: The pernicious legacy of financial sector debt. The British Journal of Politics International Relations, 15(3), 476-492.

Vaitilingam, R. (2009). Recession Britain: Findings from economic and social research: Economic and Social Research Council Swindon.

Végh, M. Z. (2014). Has austerity succeeded in ameliorating the economic climate? The cases of Ireland, Cyprus and Greece. Journal of Social Sciences, 3(2), 288-307.

Wheatley, D., Lawton, C., \& Hardill, I. (2018). Gender Differences in Paid and Unpaid Work. In Hidden Inequalities in the Workplace (pp. 181-214): Springer. 


\section{Appendix}

Table 1: Search Strategy

\begin{tabular}{ll}
\hline Search strategy & \\
\hline Keywords & Austerity, stringent financial policies \\
& Recession \\
& Employment relations \\
& Employee morale, engagement, \\
& commitment, enthusiasm \\
\hline Outcome & Organisation response \\
& Employee response \\
\hline Context & UK, United Kingdom, England \\
& Ireland \\
\hline
\end{tabular}


Table 2- Summary of findings

Dynamics of work and employment relations in times of Austerity

\begin{tabular}{|c|c|c|c|c|}
\hline $\begin{array}{l}\text { No. of } \\
\text { studies }\end{array}$ & Study & Purpose & Organisational response & Employee response \\
\hline 1 & Roche and Teague (2014) & $\begin{array}{l}\text { To investigate HR response to } \\
\text { the effect of recession. } \\
\text { Commercial and employment } \\
\text { effect of recession }\end{array}$ & $\begin{array}{l}\text { Organisations depended more on HR managers for their } \\
\text { expertise. HR managers resorted to pay cuts and freeze } \\
\text { for all employees, introduction of lower pay scales for } \\
\text { new staff, reduced overtime and changing pension } \\
\text { arrangement for staff. Unionised firms solicited the } \\
\text { inputs of union leaders in the decisions on work and } \\
\text { employment practices. Voluntary and involuntary } \\
\text { redundancies were practiced by some of the } \\
\text { organisations. }\end{array}$ & $\begin{array}{l}\text { Did not investigate employees' } \\
\text { responses }\end{array}$ \\
\hline 1 & $\begin{array}{l}\text { Cook, Mackenzie and Forde } \\
\text { (2016) }\end{array}$ & $\begin{array}{l}\text { The study examined HRM } \\
\text { practices that were implemented } \\
\text { during recession that positively } \\
\text { affected short term financial } \\
\text { value metrics }\end{array}$ & $\begin{array}{l}\text { Recruitment activities reduced. Employees were } \\
\text { stretched to work at odd hours. Hard line HR policies } \\
\text { were put in place with little or no input/support from } \\
\text { employees and union representatives. Jobs were } \\
\text { enlarged with more intensity without corresponding } \\
\text { increase in staff. }\end{array}$ & $\begin{array}{l}\text { Employees accept jobs and tasks } \\
\text { that are outside of comfort for fear } \\
\text { of losing their jobs. Employees } \\
\text { showed negative emotions and wide } \\
\text { discontentment for policies but } \\
\text { accepted them. }\end{array}$ \\
\hline 2 & $\begin{array}{l}\text { Sahdev (2003); Loretto et al. } \\
2013\end{array}$ & $\begin{array}{l}\text { The studies investigate how } \\
\text { organisations respond to austerity } \\
\text { and how employees who were } \\
\text { left after downsizing responded } \\
\text { to changes in the organisation }\end{array}$ & $\begin{array}{l}\text { Common trends to summarise the response of } \\
\text { organisations include restructuring, redundancy, change } \\
\text { in culture and business transformation programmes. } \\
\text { The trigger for downsizing for the government } \\
\text { organisation for austerity and policy changes, while the } \\
\text { private sector organisations downsized for reasons such } \\
\text { as changes in technology, competitors, fall in profit and } \\
\text { cost. Organisations were also employing more older } \\
\text { workers who would prefer flexible work }\end{array}$ & $\begin{array}{l}\text { Lack of trust at all levels, increased } \\
\text { workload, job in security, low } \\
\text { morale, survivor envy, lack of } \\
\text { psychological contract, sense of } \\
\text { pride for survivors, low commitment }\end{array}$ \\
\hline 1 & Lewis et al. (2017) & $\begin{array}{l}\text { The study investigated how work } \\
\text { life balance was practised in the } \\
\text { public sector after the financial } \\
\text { crisis }\end{array}$ & $\begin{array}{l}\text { The study reported that WLB was embedded in the } \\
\text { organisations such that it was widely accepted } \\
\text { irrespective of the financial pressures. A further strand } \\
\text { of finding showed that WLB was utilised as a tool for } \\
\text { managing financial pressures. Organisations also } \\
\text { considered WLB as construct that should be the } \\
\text { responsibility of the individual employees }\end{array}$ & $\begin{array}{l}\text { Although some of the participants } \\
\text { noted the neglect of employees } \\
\text { needs and reactions to the } \\
\text { application of WLB, it was not } \\
\text { covered in this study }\end{array}$ \\
\hline
\end{tabular}



(2013), Hasting and Heyes (2018) Muller et al. (2015)
The study examined how nonprofit organisations implemented employment policies aimed a personalising social services during the period of austerity

The study examined how local councils in the UK implemented the gender equality duty during the times of austerity

The studies examined how underemployment as exacerbated by the great recession influenced workers well-being and how national governments influenced work and employment relations policies

The study examined the effect of the 2008-2009 recession on the powers of trade unions across Europe (Germany, UK, Spain and Sweden)

The studies investigate how trade unions were able to sustain

collective bargaining during times of recession

The studies investigate how the implementation of lean

management affect employees
Personalisation policy during austerity resulted in cuts in the services provided to service users, with employees spending less time with clients with the aim of reaching more clients. Training was provided to employees to enable multitasking, redeployment opportunities were limited, increased zero contract and employment of relief staff

The need to transform business operations to fit with funding constraint made gender equality duty (GED)lost it immediacy. There was a shift in the focus of equality from employees to service delivery. There was little or no input from the unions on the GED policy. GED was not a consideration for pay negotiation

The used implementation of marketisation approach was evident. Government introduced 'flexicurity' allowing workers to engage in flexible work while guaranteeing their employment. Increase job sharing and reduced worker protection.

\section{Did not focus on organisational response.}

Did not focus on organisational response.

Organisation respond to austerity was to introduce machines that will replace some of the jobs of employees. Cutting of jobs and increased workload
Did not investigate employees' responses, but acknowledged the need to investigate the effects that employment relations policies during austerity may have on employees' attitude and behaviour

There was no mention of the effect that the non-implementation of the GED policy had on the attitude and behaviour of employees.

Data collected at different times show that the workers dissatisfaction with their jobs and opportunities increased substantially during the period 2006 to 2012. Workers wellbeing deteriorated due to unsatisfactory workload The powers of trade union to challenge austerity policies due to recession was generally weakened

Findings showed that trade unions bargained for pay by coordinating their activities sector by sector.

Consequently, trade unions were able to fight austerity policy with regards to pay

performance and quality of employee output dropped.

Employees did not experience the upscaling of skills put forward as part of the rationale by managers. Increased emotional labour 
Bach (2012, 2016), Bach and Bordogna (2013), Bach and Stroleny (2013)

1

O'Rourke (2020)

6 Mercille and Murphy (2015), Johnson, Rubery and

Grimshaw (2019), Scott and

Williams (2014), Holboow

(2012), Dobbins and Dundon (2016), Hayes (2017)
The studies examined how the implementation of volunteerism influenced employee output and behaviour toward volunteers

Focus on the implementation of new public management approach in the non-profit and voluntary sector

The focus here was the implementation of neoliberalisation approach and marketisation approach to employment relations
Organisation respond to austerity was to introduce freeze employment and to fill existing low level/skil jobs with volunteers who consider the jobs as a way to give back. Poor consultation with trade union

Introduction of business facing strategies to work and HRM, pressure on pay

Increased commercialisation leading to labour casualisation and erosion of working conditions.

Introduced one sided information and consultation partnership with employees
This reduced employees' power to pressurise management for

improved terms and conditions. The trade union responded with strike actions

Increased frustration levels, evidence of coasting, work intensification, work to rules level

Did not investigate employees' responses 


\section{Figure 1- Article selection criteria}

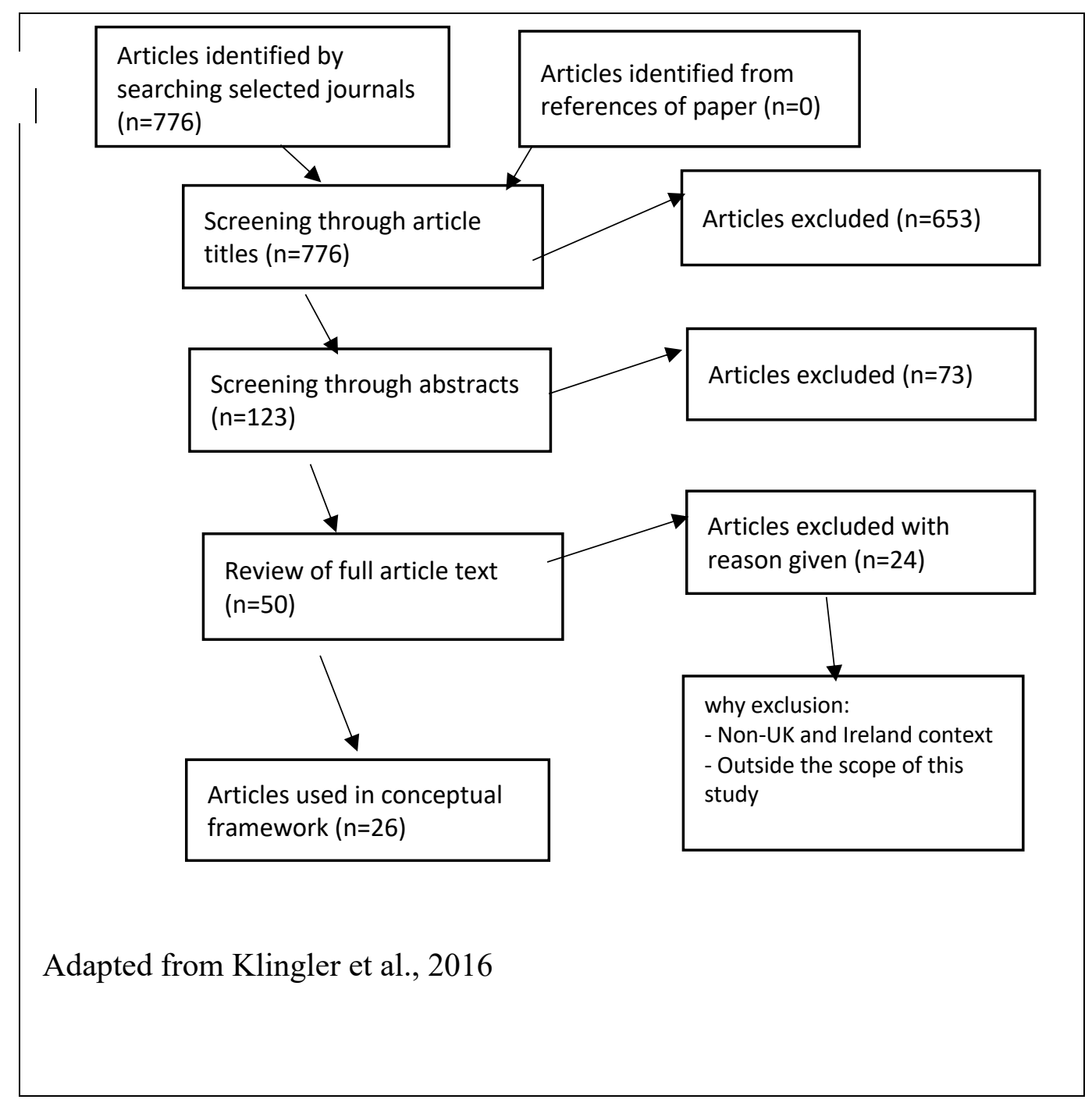


Figure 2- Propose conceptual framework for future studies

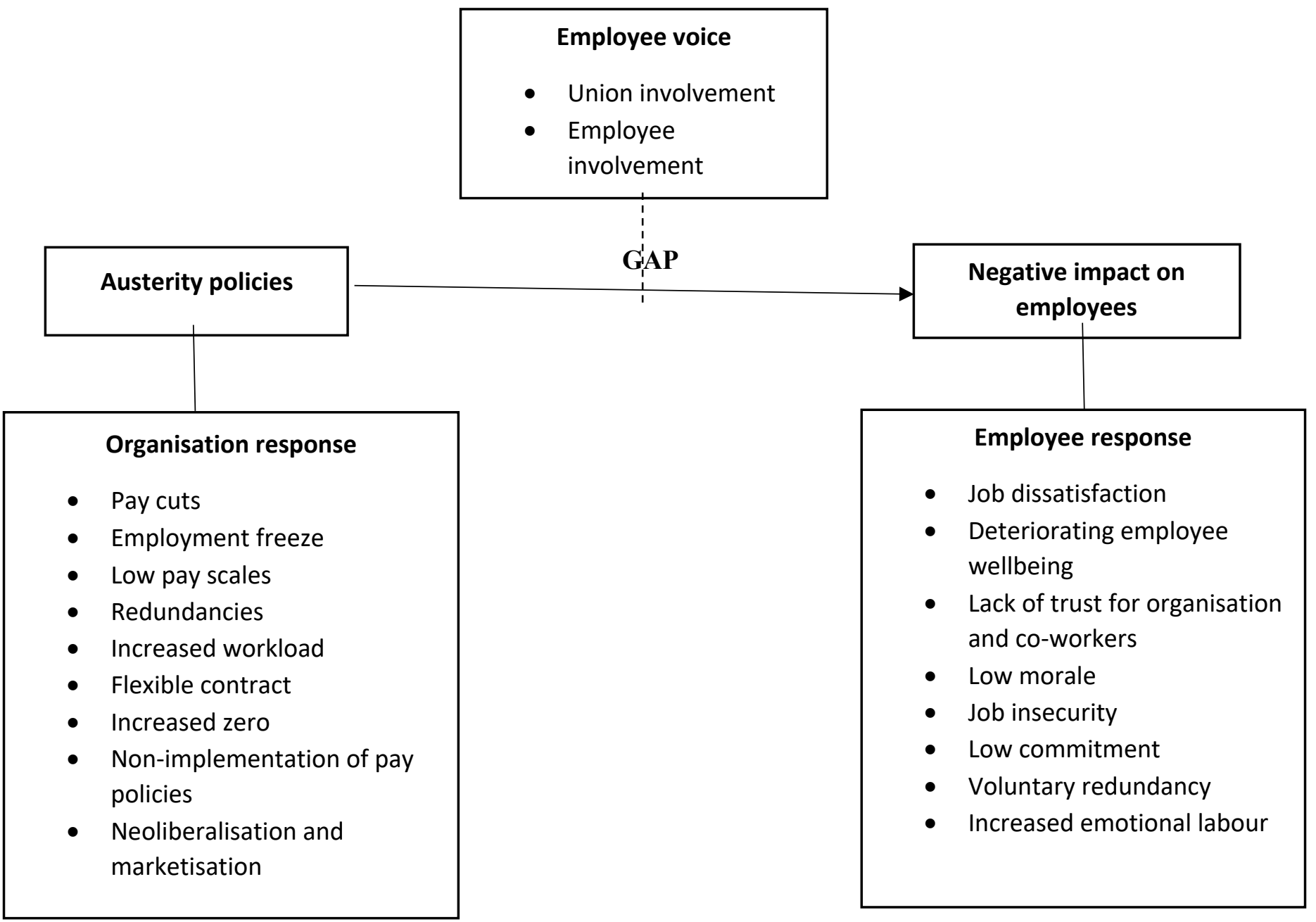

